\title{
Long-term behavior of mortars produced with sulfide-bearing aggregates
}

\author{
Ana Paula Marcelino ${ }^{1}$, José Márcio Calixto ${ }^{2}$, Adriana Gumieri ${ }^{3}$
} Cláudia Lima Caldeira ${ }^{4}$, Maria Cecília Ferreira ${ }^{5}$

\author{
${ }^{1,2}$ Federal University of Minas Gerais (UFMG), Department of Structural Engineering, Av. Antonio Carlos 6627, 30270- \\ 901 Belo Horizonte, MG, Brazil. \\ e-mail: apmarcelino84@gmail.com, calixto@dees.ufmg.br \\ ${ }^{3}$ Federal University of Minas Gerais (UFMG), Department of Construction Materials Engineering, Av. Antonio Carlos \\ 6627, 30270-901 Belo Horizonte, MG, Brazil. \\ e-mail: adriana@demc.ufmg.br \\ ${ }^{4}$ Federal University of Minas Gerais (UFMG), Department of Metallurgical and Materials Engineering, Av. Antonio \\ Carlos 6627, 30270-901 Belo Horizonte, MG, Brazil. \\ e-mail: claudia@demet.ufmg.br \\ ${ }^{5}$ MC Soluções Engenharia, Rua Dr Luiz Antônio Waack 831, 38405-327 Uberlândia, MG, Brazil \\ e-mail: mceciliafirmo@gmail.com
}

\begin{abstract}
The variety of sulfides (inorganic compounds formed by combining sulfur with a metal element) presented in earth crust is not small, which makes it difficult to avoid the use of sulfide-bearing aggregates in the concrete, especially in places where another source of material is non-existent or economically impracticable, as is the case of dams. Within this scenario, this work presents an evaluation of the long-term behavior of mortar produced with aggregates containing pyrite and pyrrhotite. For the study, rock samples from the Irapé Hydroelectric Power Plant area in Minas Gerais were used. This plant was built in a geological site where the rock presented sulfide levels of at least 3\%. These rock samples were first ground and then used as aggregates in mortars, which were, during almost 1300 days, subjected to three different exposed conditions: 1-temperature of $23^{\circ} \pm 2^{\circ} \mathrm{C}$ and relative humidity of 95 to $100 \%$; 2 - submerged in calcium hydroxide solution diluted in water during almost 850 days and then kept in water up to 1300 days, both at room temperature; 3- submerged in calcium hydroxide solution diluted in water at $50^{\circ} \mathrm{C}$ during almost 850 days and then kept in water $\left(50^{\circ} \mathrm{C}\right)$ up to 1300 days. The expansion caused by the iron sulfide oxidation as well as the content of each sulfide were evaluated over time. The presence and amount of pyrrhotite were obtained from a leaching process of the material (aggregate or mortar) in a solution of hydrochloric acid. This procedure allowed also the evaluation of the pyrite content over time. The results showed that the calcium hydroxide solution speeds up the expansion just like the temperature. It was also observed that the amount of pyrite has remained virtually constant over time in the three exposure situations. This finding indicates that sulfur limits in aggregates should be set according to the type of iron sulfide presented and not only by the total amount of sulfur.
\end{abstract}

Keywords: sulfide-bearing aggregates, mortar, long-term behavior, dams.

\section{INTRODUCTION}

On the Earth, the lithological variety is huge and, consequently, aggregates for concrete come from many rocks containing sulfides in their mineralogical constitution. These sulfides are pyrite, pyrrhotite, marcasite, chalcopyrite, arsenopyrite, sphalerite, galena, among others. It can be concluded that it is difficult to avoid the use of these aggregates in the concrete. This is even more difficult in places where the availability of another source of material is economically impracticable or non-existent as in the case of concrete dams where large volumes of aggregates are needed [1,2].

The effect of the presence of sulfide-bearing aggregates in concrete with respect to strength and durability of the material has been the subjected of several studies $[1,3,4,5]$. On the other hand, most of the design specifications that deal with the subject prescribe a limit value for the total sulfur in the aggregates and do not differentiate the type of sulfide: pyrite $\left(\mathrm{FeS}_{2}\right)$ or pyrrhotite $\left[\mathrm{Fe}_{(\mathrm{x}-1)} \mathrm{S}\right]$. An exception is the European 
standard EN 12620:2008 [6], which recommends that, if pyrrhotite is detected in the aggregate composition, the maximum value of total sulfur should not exceed $0.1 \%$. This value is 10 times smaller than the usually accepted one for aggregates containing iron sulfides. According to Chinchón-Payá et al. [4], this value is considered extremely small by many engineers and may have caused the unnecessary disposal of aggregates that could be suitable for producing concrete.

Pathologies have been observed in concrete foundations of several homes in the Trois-Rivière region of Quebec, Canada [7]. Aggregates containing sulfides (sulfur content between $0.73 \%$ and $1.28 \%$ by mass) were used in the concrete composition. The pathologies were characterized by a rapid deterioration in residential constructions. They appeared between 2 and 5 years after their completion of the building. In some cases, the severity of the deterioration was such that many structures had to be rebuilt and the corresponding cost reached about 80 to $100 \%$ of the actual value of the houses. In this aggregate pyrrhotite and pyrite are the most common sulfide minerals. The petrographic examination of deteriorated concrete specimens obtained from the house foundations revealed that the pyrrhotite was deeply oxidized, while pyrite showed only traces of oxidation.

Based on the above findings, Rodrigues et al. (2015) [8] developed a performance test that reproduced, in the laboratory, the deterioration mechanism observed on site. Sets of mortar bars were made and subjected to different conditions of temperature, relative humidity, immersion in bleach and drying cycles. Mortar prismatic bars were made with a w/c of 0.65 and their expansion monitored over time. Specimens were maintained at $60{ }^{\circ} \mathrm{C}$ and at $80 \%$ relative humidity and subjected to two weekly immersion cycles in bleach $(6 \%)$ at room temperature. The bars reached a nearby expansion of $0.020 \%$ in 60 days and $0.025 \%$ in 130 days.

In Brazil, the concern with the use of sulfide-bearing aggregates is relatively recent, and only during the implantation phase of the Irapé Hydroelectric Power Plant (HPP), located in the Jequitinhonha Valley in Minas Gerais, has studies begun to emerge. At this site, rocks with high sulfur contents were found, with sulfide levels of at least 3\%, which the predominance of pyrrhotite [9]. Due to these findings, aggregates from the obligatory excavations of the Irapé rock were not used [10]. This resolution was due to the lack of national standards and information about materials that could effectively contribute to minimize or prevent the deleterious phenomenon of sulfide oxidation present in the aggregates. Thus, materials from the Olhos d'Água and Córrego do Bonito quarries were investigated for the preparation of the concretes. The studies determined the use of aggregates from the Olhos d'Água quarry located six kilometers from the Irapé HPP. These aggregates contained less than $0.5 \%$ in sulfide content $[9,10]$.

There is a significant difference between the oxidation products derived from pyrrhotite and pyrite. Pyrite is generally more stable than pyrrhotite [11]. In this way, it is important to identify the different types of sulfides present in the concrete and the consequences of their presence on its behavior, since the sulfides present different oxidation behavior when submitted to the same conditions.

Based on this scenario, the objective of this paper is to present an evaluation of the behavior of mortar produced with sulfide-bearing aggregates. Mortar bars were exposed to three different conditions situations. Expansions as well as the amount of iron sulfides, pyrite, and pyrrhotite, were evaluated up to approximately 1300 days of exposure.

\section{MATERIALS AND EXPERIMENTAL PROCEDURES}

\subsection{Materials}

The aggregates used in the mortar came from rotary drilling samples of Irapé dam rock formation that was crushed and sieved. This material had an average sulfur content of $2 \%$, which is equivalent to average iron sulfide content (pyrite + pyrrhotite) of 5\%, due to these compounds stoichiometry.

To have good concrete workability during batching, different aggregate size compositions were investigated [12]. Aggregates were first crushed and sieved to achieve the size distribution according to the requirements of NBR 15577 - part 4 (ABNT, 2008) [13]. However, after crushing and sifting, the produced material did not meet this code prescribed size distribution. Due to this fact, it was decided to employ the actual size distribution of the material obtained after the crushing and sieving procedures. The best result was obtained with $80 \%$ of aggregates retained between sieves 4.8 and $0.6 \mathrm{~mm}$ and the remaining $20 \%$ consisting of material retained between sieves 0.3 and $0.1 \mathrm{~mm}$.

Brazilian Type CP V ARI cement was used in mortar production. The choice of this type of cement was because it did not contain any additional cementitious materials in its composition. The concrete mix 
proportion was 1:2.25 (cement: aggregates) by weight and the water/cement ratio was equal to 0.47 . No plasticizer was employed. The values for the mix proportion and the water/cement ratio were according to NBR 15777 [13] and ASTM C 1260 [14].

\subsection{Experimental procedures}

Cylindrical and prismatic mortar specimens were cast according to the NBR 5738[15] and the NBR 15577 [13] standards, respectively. The specimens were stripped from the molds 24 hours after casting and transferred immediately to each one of the exposed conditions. The cylindrical specimens were used in the sulfide content evaluation while the prismatic beams for measuring expansion. According to LNEC E 251 [16], expansive strains equal or greater than $3 \times 10^{-4}$ after one to two months indicate that the aggregates are not suitable to be used in concrete or when at the end of six months, these deformations exceed $5 \times 10^{-4}$.

Mortar specimens were exposed for almost 1300 days to three different conditions:

1 - Temperature of $23^{\circ} \pm 2^{\circ} \mathrm{C}$ and relative humidity of 95 to $100 \%$;

2 - Submerged in calcium hydroxide solution diluted in water at room temperature for almost 850 days and then kept in water (room temperature) up to 1282 days;

3- Submerged in calcium hydroxide solution diluted in water at $50^{\circ} \mathrm{C}$ for almost 850 days and then kept in water $\left(50^{\circ} \mathrm{C}\right)$ up to 1273 days.

The mortar expansion was measured over time using the equipment shown in Figure 1 . In order to evaluate the real expansions of the specimens immersed in the solution at $50{ }^{\circ} \mathrm{C}$, it was necessary to adjust the values to take into account the expansion caused by the temperature. The expansion caused by the temperature was calculated according to equation 1 :

$$
\varepsilon=100 . \alpha \cdot \Delta \mathrm{T}
$$

where:

$\varepsilon$ - expansive deformation due to temperature $(\%)$

$\alpha$ - concrete coefficient of thermal expansion $=1 \times 10^{-5} /{ }^{\circ} \mathrm{C}$

$\Delta \mathrm{T}-$ average temperature variation $=\left(50^{\circ} \mathrm{C}-27^{\circ} \mathrm{C}\right)=23^{\circ} \mathrm{C}($ on average $)$

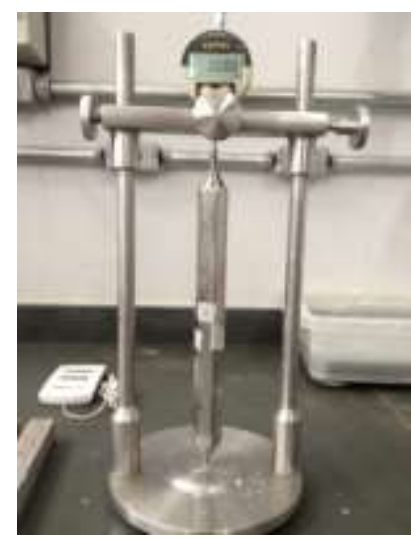

Figure 1: Equipment used to measure the expansion of the prismatic specimens.

In this way, an average expansion of $0.023 \%$ was obtained due to the temperature which was subtracted from the result of the expansion reading, so that only the expansion caused by the sulfide reactions was considered.

The total sulfur, pyrite and pyrrhotite contents over time were evaluated as follows. First, a piece of mortar was crushed to a grain size smaller than or equal to $0.15 \mathrm{~mm}$. They were then dried in an oven at $40^{\circ} \mathrm{C}$, for approximately 24 hours for water evaporation. The total sulfur content was then determined through direct combustion (with infrared detection) using the equipment LECO SC 632 (Figure 2). 


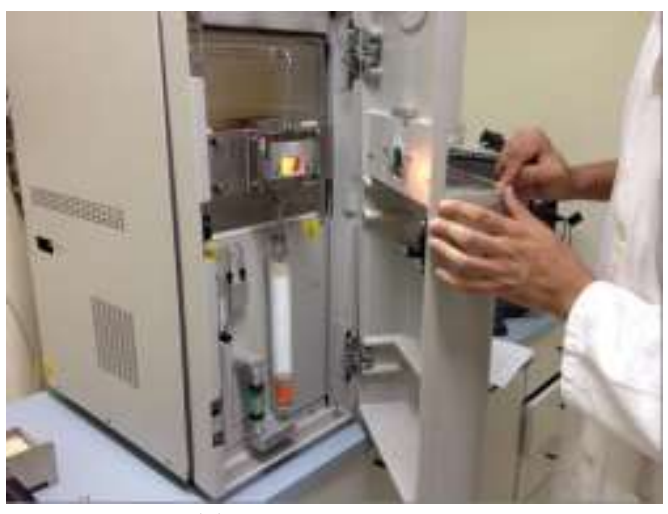

(a)

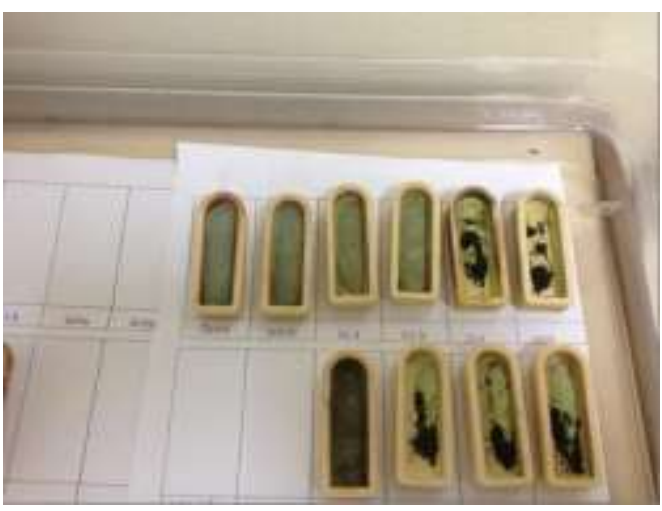

(b)

Figure 2: (a) LECO SC 632 equipment - (b) Sample preparation for sulfur evaluation.

For the evaluation of the content of the different iron sulfides, a leaching process was employed [12]. For the selective dissolution of the pyrrhotite, $1 \mathrm{~g}$ of the smashed mortar sample was blended with a $100 \mathrm{ml}$ hydrochloric acid solution $(\mathrm{HCl})$, in the proportion of $(1: 1)$ in an Erlenmeyer flask, and agitated for an hour at $60^{\circ} \mathrm{C}$. Next, the material was put in a funnel containing a filter paper to drain the solution. The material was then washed with distilled water until all $\mathrm{HCl}$ could be removed. Then the remaining material was dried in an oven at $40^{\circ} \mathrm{C}$ for 24 hours. A portion of this dried material was subjected to direct combustion testing (LECO) for determination of total residual sulfur content, which corresponds to the sulfur-pyrite content. The difference between the total initial sulfur content (not leached) and the residual content (sulfur-pyrite) corresponds to the sulfur content from the pyrrhotite and from cement.

This residue was then subjected to nitric acid leach to remove all the remaining pyrite. The final sulfur content was measured again to make sure all the pyrite had been dissolved. The sulfur quantification was done up to, approximately, 1300 days for each exposure situation.

The total sulfur content in the cement was $1.07 \%$, which results in a $0.29 \%$ sulfur content in the mortar due to the cement rate (Marcelino [17]).

\section{RESULTS AND DISCUSSION}

Figure 3 shows the expansion test results evaluated up to 1300 days after casting for all the three exposed conditions. The expansion observed after 60 days reaching $0.021 \%$ for the mortar at $23^{\circ} \mathrm{C}$ and relative humidity of 95 to $100 \%$. For bars submerged in calcium hydroxide solution, the expansion was $0.030 \%$ at room temperature and $0.037 \%$ at $50{ }^{\circ} \mathrm{C}$. After 125 days the expansions were $0.024 \%, 0.032 \%$ and $0.036 \%$ respectively. The values of mortar in $23^{\circ} \mathrm{C}$ and relative humidity of 95 to $100 \%$ are close to those obtained by Rodrigues et al. (2015) [8]. The bars submerged in solution showed higher expansions indicating that the calcium hydroxide accelerates the expansion process.

The results also indicate that the temperature accelerates the process. The calcium hydroxide solution kept at $50^{\circ} \mathrm{C}$ speeds up the expansion in the first 250 days of exposure. On the other hand, the same level of expansion was reached for the calcium hydroxide solution kept at room temperature only after 850 days. In both cases, the strain values are in the order of $0.052 \%$ and remained stable after 850 days. The specimens kept at a temperature of $23^{\circ} \pm 2^{\circ} \mathrm{C}$ and relative humidity of 95 to $100 \%$ are still expanding. 


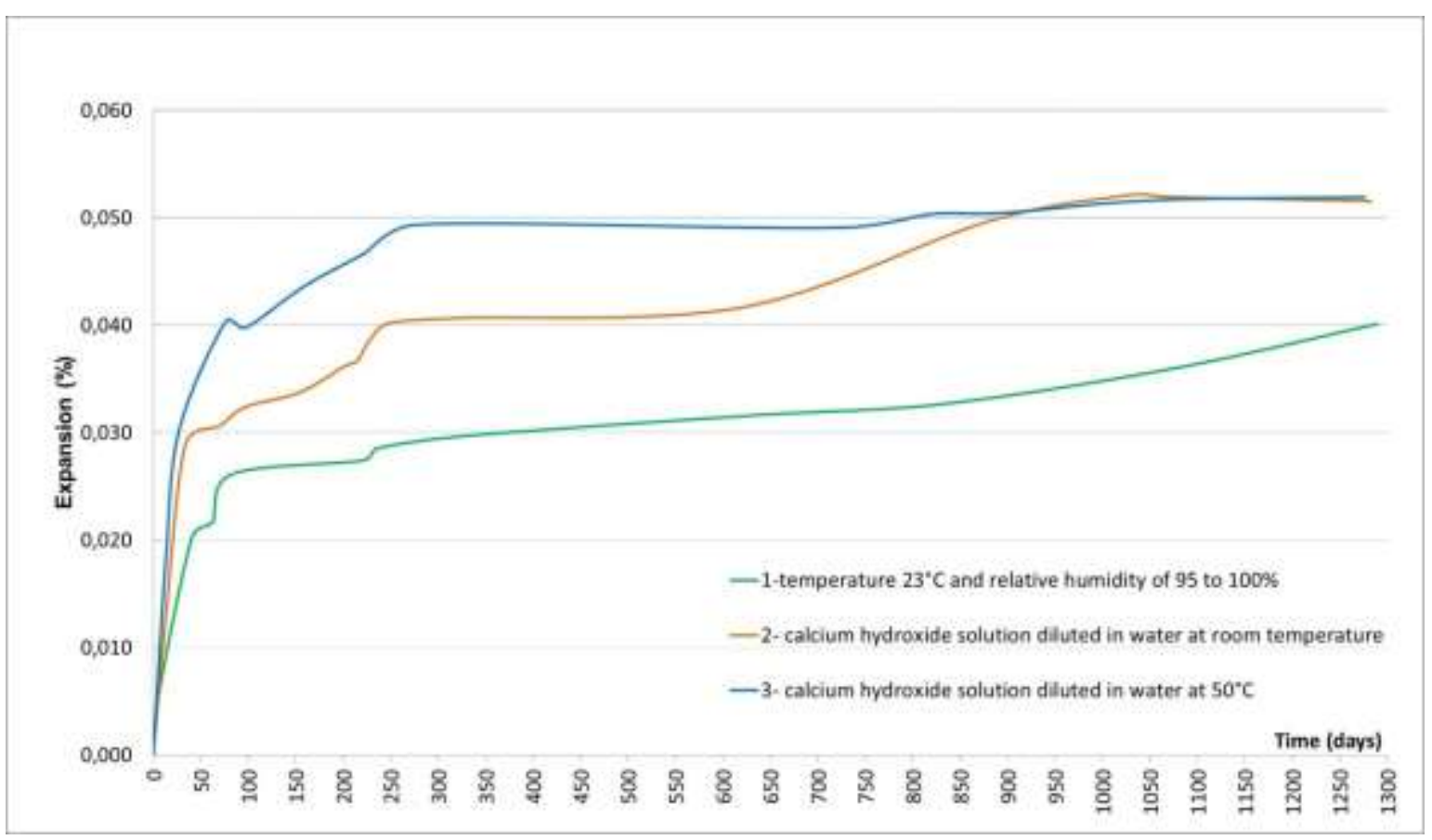

Figure 3: Expansion test results.

It is important to mention that the measured strains did not reach the limit of $0.05 \%$ at the end of six months established by LNEC E 251 [16] for any exposed conditions. For the specimens subjected to the calcium hydroxide solution, both at room temperature and at $50^{\circ} \mathrm{C}$, the measured strains exceeded the value of $0.03 \%$ after 30 days of exposure. However, no cracking was observed in the bars regardless of the exposure condition after more than 3 years of evaluation (Figure 4).

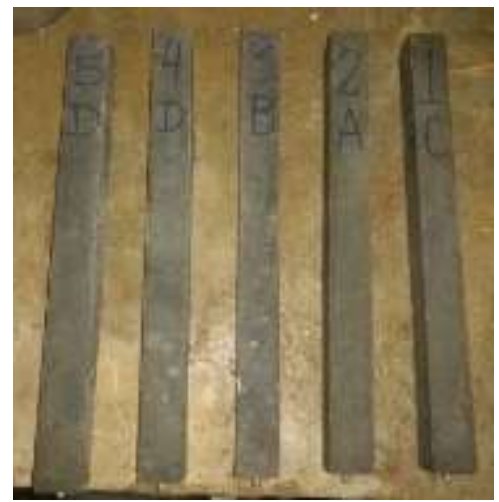

(a)

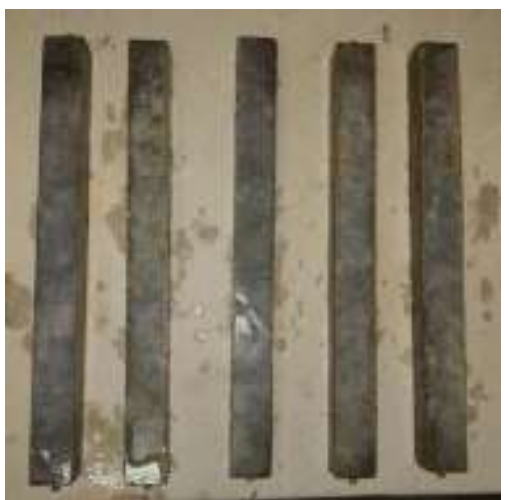

(b)

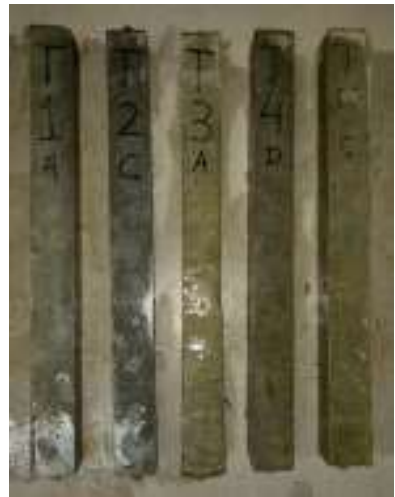

(c)

Figure 4: Concrete specimens after more than 1200 days of exposure in the three different conditions: (a) Specimens exposed to a temperature of $23^{\circ} \pm 2^{\circ} \mathrm{C}$ and relative humidity of 95 to $100 \%$ after 1286 days; (b) Specimens submerged in calcium hydroxide diluted in water at room temperature after 1282 days of exposure; (c) Bars submerged in calcium hydroxide solution diluted in water at $50^{\circ} \mathrm{C}$ after 1273 days of exposure.

The total sulfur, sulfur-pyrite and sulfur-pyrrhotite contents over time for each exposure condition are presented in Tables 1 to 3 . 
Tabel 1: Results of total sulfur, pyrite and pyrrhotite contents for specimens kept at a temperature of $23^{\circ} \pm 2^{\circ} \mathrm{C}$ and relative humidity of 95 to $100 \%$.

\begin{tabular}{c|c|c|c|c}
\hline $\begin{array}{c}\text { AGE } \\
\text { (DAYS) }\end{array}$ & $\begin{array}{c}\text { TOTAL SULFUR } \\
(\boldsymbol{\%})\end{array}$ & $\begin{array}{c}\text { SULFUR IN THE } \\
\text { CEMENT (\%) }\end{array}$ & $\begin{array}{c}\text { SULFUR FROM } \\
\text { PYRITE (\%) }\end{array}$ & $\begin{array}{c}\text { SULFUR FROM } \\
\text { PYRRHOTITE (\%) }\end{array}$ \\
\hline 27 & 1.49 & 0.29 & 0.37 & 0.83 \\
\hline 79 & 1.48 & 0.29 & 0.33 & 0.82 \\
\hline 616 & 1.44 & 0.29 & 0.32 & 0.79 \\
\hline 1286 & 1.40 & 0.29 & 0.36 & 0.75 \\
\hline
\end{tabular}

Tabel 2: Results of total sulfur, pyrite and pyrrhotite contents for specimens submerged in calcium hydroxide solution diluted in water at room temperature for almost 850 days and then kept in water (room temperature) up to 1282 days.

\begin{tabular}{c|c|c|c|c}
\hline $\begin{array}{c}\text { AGE } \\
\text { (DAYS) }\end{array}$ & $\begin{array}{c}\text { TOTAL SULFUR } \\
(\boldsymbol{\%})\end{array}$ & $\begin{array}{c}\text { SULFUR IN THE } \\
\text { CEMENT (\%) }\end{array}$ & $\begin{array}{c}\text { SULFUR FROM } \\
\text { PYRITE (\%) }\end{array}$ & $\begin{array}{c}\text { SULFUR FROM } \\
\text { PYRRHOTITE (\%) }\end{array}$ \\
\hline 27 & 1.52 & 0.29 & 0.43 & 0.80 \\
\hline 90 & 1.58 & 0.29 & 0.43 & 0.86 \\
\hline 609 & 1.43 & 0.29 & 0.44 & 0.70 \\
\hline 1282 & 1.38 & 0.29 & 0.40 & 0.69 \\
\hline
\end{tabular}

Tabel 3: Results of total sulfur, pyrite and pyrrhotite contents for specimens submerged in calcium hydroxide solution diluted in water at $50^{\circ} \mathrm{C}$ for almost 850 days and then kept in water (at $\left.50^{\circ} \mathrm{C}\right)$ up to 1273 days.

\begin{tabular}{c|c|c|c|c}
\hline $\begin{array}{c}\text { AGE } \\
\text { (DAYS) }\end{array}$ & $\begin{array}{c}\text { TOTAL SULFUR } \\
(\boldsymbol{\%})\end{array}$ & $\begin{array}{c}\text { SULFUR IN THE } \\
\text { CEMENT (\%) }\end{array}$ & $\begin{array}{c}\text { SULFUR FROM } \\
\text { PYRITE (\%) }\end{array}$ & $\begin{array}{c}\text { SULFUR FROM } \\
\text { PYRRHOTITE (\%) }\end{array}$ \\
\hline 27 & 1.62 & 0.29 & 0.37 & 0.96 \\
\hline 63 & 1.72 & 0.29 & 0.43 & 1.00 \\
\hline 602 & 1.53 & 0.29 & 0.42 & 0.82 \\
\hline 1273 & 1.52 & 0.29 & 0.46 & 0.78 \\
\hline
\end{tabular}

The expected sulfur content from pyrite in the mortar was $0.37 \%$ as verified by MARCELINO [17]. This result is very close to the values shown in Tables 1 to 3 and remains practically constant over time independently of the exposure condition. A reduction of the total sulfur content is observed in all cases over time due to the oxidation process of pyrrhotite. These results corroborate the findings by Rodrigues et al. (2012) [7] and Casanova et al. [11]: pyrrhotite oxidizes much more than the pyrite when subjected to the same environmental conditions.

\section{CONCLUSIONS}

The results indicate that the calcium hydroxide solution kept at $50^{\circ} \mathrm{C}$ speeds up the expansion in the first 250 days of exposure. On the other hand, the same level of expansion was reached for the calcium hydroxide solution kept at room temperature only after 850 days. In both cases, the strain values are in the order of $0.052 \%$ and remained stable after 850 days. The specimens kept at a temperature of $23^{\circ} \pm 2{ }^{\circ} \mathrm{C}$ and relative humidity of 95 to $100 \%$ are still expanding. However, the studied aggregate did not reach the expansion limits of $0.05 \%$ at the end of six months established by LNEC E 2511 [16] for any exposed conditions.

Although the aggregate had sulfur content larger than is currently accepted by the technical community, no cracking was observed in the specimens regardless of the exposure condition after more than 3 years of evaluation.

The results also show that the pyrite content in the mortars remained virtually constant over time independently of the three exposure situations. This result indicates that the sulfur content limits in aggregates should be set according to the type of iron sulfide presented and not solely by the total amount of sulfur. 


\section{BIBLIOGRAPHY}

[1] ARAÚJO, G. S., CHINCHÓN, J. S., AGUADO, A., "Evaluation of the behavior of concrete gravity dams suffering from internal sulfate attack", Revista Ibracon de Estruturas e Materiais, v. 1, n. 1, pp. 84-112, 2008. doi: 10.1590/S1983-41952008000100005.

[2] BATISTA, D. G., "Investigação da Deterioração de Concretos de UHEs por Reações com Agregados", Dissertação de Mestrado, Universidade Federal de Goiás, Escola de Engenharia Civil, Programa de PósGraduação em Geotecnia, Estruturas e Construção Civil, Goiânia, 2013.

[3] GOMIDES, M. J., CINCOTTO, M. A., HASPARYK, N. P., et al., "Study of Aggregates with Sulphides in Cement Composites", Revista Ibracon de Materiais, v. 1, n. 1., pp. 29-38, 2007.

[4] CHINCHÓN-PAYÁ, S., AGUADO, A., CHINCHÓN, S., "A comparative investigation of the degradation of pyrite and pyrrhotite under simulated laboratory conditions", Engineering Geology, 2012, v. 127, p. 75-80. doi: 10.1016/j.enggeo.2011.12.003.

[5] PEREIRA, E., PORTELLA, K. F., BRAGANÇA, M. P., et al., "Pyrite Oxidation and its effects on Portland cement mortars subject to internal sulfates attack (ISA)", Revista Matéria, v. 21, n. 2, p. 342-354, 2016. doi: 10.1590/S1517-707620160002.0033

[6] EUROPEAN NORM, Aggregates for concrete, EN: 12620:2008.

[7] RODRIGUES, A., DUCHESNE, J., FOURNIER, B., et al., "Mineralogical and Chemical Assessment of Concrete Damaged by the Oxidation of Sulfide-Bearing Aggregates: Importance of Thaumasite Formation on Reaction Mechanisms", Cement and Concrete Research, v. 42, pp. 1336-1347, 2012. doi: 10.1016/ j.cemconres.2012.06.008.

[8] RODRIGUES, A., DUCHESNE, B., FOURNIER, B., "A new accelerated mortar bar test to assess the potential deleterious effect of sulfide-bearing aggregate in concret", Cement and Concrete Research, 2015, v. 73, p. 96-110. doi: 10.1016/j.cemconres.2015.02.012.

[9] CEMIG GERAÇÃO E TRANSMISSÃO S. A., UHE Irapé - P\&D 122 - Investigação do comportamento do concreto e da calda de cimento em contato com rocha sulfetada, Belo Horizonte, 2007.

[10] CONSÓRCIO LEME-INTERTECHNE. UHE Irapé - Estudos e projetos complementares - Relatório Descritivo da Situação Atual dos Trabalhos (Documentação para a junta de consultores da CEMIG), 1999, $104 \mathrm{p}$.

[11] CASANOVA, I., AGUADO, A., AGULlÓ, L., "Aggregate Expansivity due to Sulfide Oxidation - II Physico-Chemical Modeling of Sulfate Attack", Cement and Concrete Research, v. 27, n. 11, pp. 1627-1632, 1997.

[12] MARCELINO, A. P., CALIXTO, J. M., GUMIERI, A. G., et al., "Evaluation of pyrite and pyrrhotite in concretes", Revista Ibracon de Estruturas e Materiais, v. 9, n. 3, pp. 484-493, 2016. doi: 10.1590/S198341952016000300009.

[13] ASSOCIAÇÃO BRASILEIRA DE NORMAS TÉCNICAS (ABNT), NBR 15577 - Agregados - Reatividade álcali-agregado - Parte 4 - Determinação da expansão em barras de argamassa pelo método acelerado, 2008, Rio de Janeiro, Brasil.

[14] AMERICAN SOCIETY FOR TESTING MATERIALS (ASTM), C 1260 - Standard test method for potential alkali reactivity of aggregates (mortar-bar method), 2007, West Conshohocken, United States of America.

[15] ASSOCIAÇÃO BRASILEIRA DE NORMAS TÉCNICAS (ABNT), NBR 5738 - Moldagem e cura de corpos-de-prova de concreto cilíndricos ou prismáticos, 1994, Rio de Janeiro, Brasil.

[16] LABORATÓRIO NACIONAL DE ENGENHARIA CIVIL (LNEC), E 251 - Inertes para Argamassas e Betões - Ensaio de Reactividade com os sulfatos em presença de hidróxido de cálcio, 1985, Lisboa, Portugal.

[17] MARCELINO, A. P., "Estudos para o desenvolvimento de uma metodologia de definição de teores deletérios de enxofre em concretos e argamassas de barragens", Dissertação de Mestrado, Programa de Pósgraduação em Engenharia de Estruturas da Escola de Engenharia da Universidade Federal de Minas Gerais, 2015, Belo Horizonte.

\section{ORCID}

Ana Paula Marcelino José Márcio Calixto 
Cláudia Caldeira

Maria Cecília Ferreira https://orcid.org/0000-0002-7355-3015

https://orcid.org/0000-0001-6757-4576 